\title{
Examining The Use of Hofstede's Uncertainty Avoidance Construct in International Research: A 25-Year Review
}

\author{
Jenny K. Rapp, Richard A. Bernardi (corresponding author) \& Susan M. Bosco \\ Gabelli School of Business, Roger Williams University, Bristol, Rhode Island, USA \\ E-mail: jrapp770@g.rwu.edu / rbernardi@rwu.edu / sbosco@rwu.edu
}

\begin{abstract}
The goal of this research was to determine the manner in which Hofstede's uncertainty avoidance construct has been incorporated into international research. Hofstede's work is often referenced in this realm of work, but how, specifically, is it used? This study provides a framework of this dimension from Hofstede's work that other researchers can use as a resource for planning articles and/or as a benchmark upon which to develop further studies. During our data gathering, we identified 118 articles in the Journal of International Business Studies (i.e., the outlet for his initial article) that used Hofstede's uncertainty avoidance. Three articles mentioned uncertainty avoidance in the research notes and 15 used uncertainty avoidance to support positions taken in the literature review. Forty-one articles used uncertainty avoidance while explaining their research hypotheses. Of the remaining 59 articles, 29 used Hofstede's data to compare countries using composite indices, and 30 used uncertainty avoidance as an independent or control variable.
\end{abstract}

Keywords: Hofstede, Cultural Constructs, Uncertainty Avoidance

\section{Introduction}

Hofstede believes that culture is a system of shared values and beliefs that represent a "set of likely reactions of citizens with a common mental programming. . . . reactions need not be found within the same persons, but only statistically more often in the same society" (1991: 112). Consequently, uncertainty avoidance represents the collective willingness of a society to tolerate ambiguous outcomes (i.e., a cultural difference). Hofstede's (1983) uncertainty avoidance construct was calculated as a composite score of three separate factors: (a) rules orientation, (b) employment stability, and (c) nervousness or stress at work as shown in Formula 1. The rules orientation factor reflects individuals' responses to the statement: "Company rules should not be broken - even if the employee thinks it is in the company's best interests" (Hofstede, 1983: 118-119). Hofstede notes that the rules orientation factor was measured on a five-point Likert scale with one reflecting "strongly agree" and five reflecting "strongly disagree". For the rules orientation factor, higher (lower) beliefs about the need to follow rules have lower (higher) values on the Likert scale.

Uncertainty Avoidance $=300-30$ (mean score rule orientation $)-(\%$ intending to stay less than 5 years $)-40$ (mean stress score) $\quad \ldots \ldots \ldots \ldots \ldots \ldots \ldots \ldots \ldots \ldots \ldots \ldots \ldots \ldots$ Formula 1

Hofstede states that the employment stability factor reflects individuals' responses to the statement: "How long do you think you will continue working for this company?" (1983: 119). The score for the employment stability factor was the percent of individuals who intend to remain with their current employer no more than five years. This part of the computation asked individuals to select one of the following responses: "(1) Two years at the most; (2) From two to five years; (3) More than five years (but I probably will leave before I retire); and (4) Until I retire". For the employment stability factor, longer (shorter) intentions to remain with the current employer have higher (lower) values. Hofstede indicates that the nervousness or stress at work factor reflects individuals' responses to the statement: "How often do you feel nervous or tense at work?" (1983: 119). The nervousness or stress at work factor was measured on a five-point Likert scale with one being "I always feel that way" and five being "I never feel that way". For the nervousness or stress at work factor, higher (lower) feelings of being nervous have lower (higher) values on the Likert scale.

Our study examines the existing literature in the Journal of International Business Studies to determine the manner in which Hofstede's uncertainty avoidance construct has been incorporated into international research. Hofstede's work is often referenced in this realm of work, but how, specifically, is it used (i.e., as a research note, in literature review as a definition, as part of a composite index, or as an independent or control variable). This is a longitudinal study that reviews the applications of Hofstede's research for a period of 25 years - from 1983 (i.e., when Hofstede introduced his constructs) to 2008. This study provides a framework of this dimension from Hofstede's work that other researchers can use as a resource for planning articles and/or as a benchmark upon which to develop further studies. 


\section{Overview of the Literature Review}

For the 25 years of this study, we found 118 articles. The data in Figure 1 indicate the growing use of Hofstede's work in international research published in the Journal of International Business Studies. The first article using Hofstede's (1983) cultural dimensions was in 1988, which is about five years after his initial cultural dimensions article appeared in the journal. Since then, the number of articles in the Journal of International Business Studies that have used this construct has grown at an average rate of about two articles per year. The univariate regression model using the number of years from Hofstede's (1983) original article in the journal as the independent variable indicates an adjusted $\mathrm{r}^{2}$ of 0.26 (i.e., the variable explained $26 \%$ of the variation in the model).

\subsection{Research Notes and Definition Articles}

Panel A of Table 1 is composed of three articles that mention uncertainty avoidance in only the notes section of the referenced research. Two of these articles (Jackson \& Deeg, 2008; Speck \& Roy, 2008) mention Hofstede's five cultural dimensions of power distance, uncertainty avoidance, individualism, masculinity and long-term orientation. Tihanyi et al. (2005) coded their studies using samples of Multi-National Enterprises from high to low uncertainty avoidance cultures using the quartiles of Hofstede's uncertainty avoidance index.

Panel B of Table 1 lists 15 articles (12.7 \%) that used uncertainty avoidance as a definition to support the literature review. For example, Neelankavil et al. (2000: 126) state that "uncertainty avoidance measures the extent to which people in a society tend to feel threatened by uncertain, ambiguous, risky or undefined situations." The majority of the articles in Panel B mention Hofstede's four cultural dimensions of power distance, uncertainty avoidance, individualism and masculinity. Later, Hofstede (2006) added a fifth dimension of long-term orientation.

\subsection{Research Hypothesis Articles}

Of the 118 articles we identified, 41 articles (34.7\%) used uncertainty avoidance to justify their hypotheses or used previous research to explain the effects of uncertainty avoidance (Table $2 a, b, \&$ c). Table 2a contains the 11 articles that theorized about the potential effects of uncertainty avoidance. The 14 articles in Table $2 \mathrm{~b}$ include studies that had samples from only one-or-two countries. Finally, Table 2c presents the 16 studies with three-or-more countries.

Several of these articles proposed a theory of high uncertainty avoidance for countries, cultures, societies or employees. For example, DiRienzo et al. (2007) suggest that, in societies with high uncertainty avoidance, people feel uncomfortable in unpredictable situations, which results in unwillingness to challenge authority and rules. These authors also mention that high uncertainty avoidance societies tend to be more corrupt.

Due to their need to control their environment, Money (1998) maintains that, while low uncertainty avoidance cultures are more comfortable with risk, high uncertainty avoidance cultures avoid risk (Chui et al., 2002) and seek ways to add structure or control to their environments. Leung et al. (2005) explain that resistance to change will be higher in cultures of high uncertainty avoidance, and Hirst et al. (2008) note that employees who are higher in uncertainty avoidance prefer greater standardization. For example, Turkey is classified as a high uncertainty avoidance and power distance culture, which is reflected by subordinates always accepting their superiors' directives without question (Pellegrini \& Scandura, 2006).

About a dozen of these articles used uncertainty avoidance to hypothesize or demonstrate an association or difference. For example, uncertainty avoidance is positively correlated with the preference for joint ventures and related to risk-taking behavior (Li et al., 2001; Makhija \& Steward, 2002). Sirmon and Lane (2004) note that differences in uncertainty avoidance and long-term orientation could represent differences in how partners perceive and adapt to opportunities and threats in their environments. For example, inter-partner differences in uncertainty avoidance and long-term orientation have a significant negative impact on international joint ventures (Yan \& Zeng, 1999). Wu et al. (2008) propose that uncertainty avoidance may also be related to employment discrimination. Agarwal (1993) suggests that including additional cultural factors such as uncertainty avoidance can help explain differences that may exist among countries.

The remaining articles in this section mentioned Hofstede's findings or conducted an additional analysis. Hofstede found no evidence of convergence over time with respect to the work-related values of power distance, uncertainty avoidance, individualism and masculinity (Husted et al., 1996). While Manev and Stevenson (2001) stated that cultural norms vary from country to country based on Hofstede's cultural constructs, Markides and Ittner (1994) measured the cultural distance between the United States and the target country using Hofstede's four cultural constructs. Huang and Van de Vliert (2002) conducted an additional analysis controlling for eight potential rival country-level explanatory variables - one of which was uncertainty avoidance. Although all these articles cited uncertainty avoidance in their literature review, they did not use uncertainty avoidance in their methodology.

\subsection{Cultural Distance Index Articles}

Tables 3a \& b contain the 29 articles (24.6 \%) that used Hofstede's data to compare the cultural distance between a selected country and a target country. Kogut and Singh (1988) modified Hofstede's cultural distance constructs to 
form a composite index based on the deviation for each of Hofstede's cultural constructs. Kogut and Singh (1988) used this composite index (Formula 2) to measure the distance of the target country score for that cultural dimension of the United States. Kogut and Singh's index measures this distance for each cultural dimension separately, while holding the United States as a constant.

The 24 articles in Table 3a used Kogut and Singh's index to measure the cultural distance between two countries using the United States as the control country. However, Slangden and Hennart (2008) measure cultural distance between the Netherlands (as their control country) and 35 other countries using Kogut and Singh's index. Benito and Gripsrud (1992) take a similar approach and used Kogut and Singh's index to measure the cultural distance between Norway and foreign direct investment countries.

$$
\text { Cultural Distance }=\left[\sum_{i=1}^{4}\left\{\left(I_{i i}-I_{i u}\right]^{2}\right\} / V_{i} / 4\right] \quad \ldots \ldots \ldots \ldots \ldots \ldots \ldots \ldots \ldots \ldots \ldots \ldots \text { Formula } 2
$$

Where:

$I_{i j} \quad$ Index for the $i$ th cultural dimension and $j$ th country

$V_{i} \quad$ Variance of the index of the $i$ th cultural dimension

$u \quad$ Indicates the United States

From Kogut \& Singh, 1988: 422

The five articles in Table 3b proposed adjustments to Kogut and Singh's index. For example, Uhlenbruck (2004) made an algebraic adjustment to Kogut and Singh's calculation of cultural distance (Formula 3). Additionally, he uses Trompenaars and Hampden-Turner's (1998) data while utilizing Kogut and Singh's index to calculate more than one measure at a time. For example, his adjustment allowed him to treat western and eastern Germany as two separate cultures within one country, which was not possible using Hofstede's index. Also, due to cultural changes over time within a country, Trompenaars and Hampden-Turner's more recent data provide an advantage in calculating cultural distance. Two of the five articles in Table $3 \mathrm{~b}$ do not propose a new index; however, their authors used a variation of Kogut and Singh's index. Chan and Makino (2007) build on Kogut and Singh's index for national culture in a number of dimensions including Hofstede's four classical dimensions plus long-term orientation. Griffith and Harvey (2001) use an approach similar to Kogut and Singh to provide an index of cultural distance over each dimension's variance.

Hofstede's Distance $=$

$$
\left[\sum_{\mathrm{i \in Da}}\left(I_{i a}-I_{i t}\right)^{2} / \mathrm{V}_{\mathrm{i}} /\left|\mathrm{D}_{\mathrm{at}}\right|\right]
$$
Formula 3
Where:

$\begin{array}{ll}I_{i a} & \text { Index for the } i \text { th cultural dimension for the } a \text { th country } \\ I_{i t} & \text { Index for the } i \text { th cultural dimension for the } t \text { th country } \\ V_{i} & \text { Variance of the index of the } i \text { th cultural dimension } \\ \left|\mathrm{D}_{\text {at }}\right| & \text { Number of compared measures }\end{array}$

\subsection{Independent or Control Variable Articles}

Tables $4 \mathrm{a} \& \mathrm{~b}$ contain the 30 articles $(25.4 \%)$ that used Hofstede's uncertainty avoidance construct as either an independent or control variable. Table $4 \mathrm{a}$ includes the 24 studies that used data bases or other samples that did not include human subjects. The six studies in Table $4 \mathrm{~b}$ used human subjects in the research. Of these 30 articles, 16 $(53.3 \%)$ used other readily-assessable data bases as the source of their dependent variables (i.e., data on education, disclosure, life insurance consumption and accounting standards); eight (26.7 \%) used data from surveys, and the remaining six ( $20.0 \%$ ) used financial data (i.e., percentage of foreign ownership and post-acquisition performance). Tables $4 \mathrm{a} \& \mathrm{~b}$ also include the findings of these 30 articles as they relate to uncertainty avoidance.

\section{Conclusions}

This study examined the extent and nature of the use of Hofstede's uncertainty avoidance in articles published in the Journal of International Business Studies for a period of 25 years from 1983 to 2008. The beginning of this timeframe (1983) coincides with Hofstede's initial publication of his four cultural dimensions. While these 
dimensions were introduced in 1983, our data indicate that the first article to use uncertainty avoidance in the Journal of International Business Studies was Kogut and Singh (1988). (Note 1) While we only report on Hofstede's uncertainty avoidance construct, the majority of the research we examined in the course of this study included all of Hofstede's constructs.

Our data indicate that $50.0 \%$ (59 of the 118) of the articles citing Hofstede's work used the uncertainty avoidance construct as part of their literature reviews to make the point about differences in cultures. Twenty-nine of the 118 articles (24.6\%) used Hofstede's cultural constructs in the computation of cultural distance indices. For example, Kogut and Singh (1988: 422) used the difference between the United States (control country) and the score for other countries' cultural constructs as part of the computation for their cultural difference index. Other research has used Kogut and Singh's model with a different control country. Uhlenbruck (2004) made an algebraic adjustment to Kogut and Singh's calculation of cultural distance (Formula 3) so that he could use Trompenaars and Hampden-Turner's (1998) data. The remaining 30 articles $(25.4 \%)$ were the only articles that used uncertainty avoidance as an independent or control variable.

These results indicate the continuing influence of Hofstede's uncertainty avoidance construct on international research. His initial work has engendered a significant stream of research that examined cultural differences in a variety of disciplines. It is evident from this research that Hofstede's indices still provide the basis for both theoretical and empirical work. As seen in its use in the literature reviews and notes, it provides a point of common understanding for those doing research in intercultural phenomena.

As evidenced by this study, Hofstede's work continues to be used as a basis for international research on cultural dimensions. It is used in a variety of ways: As a means of definition, as a construct for measurement, and as a basis for the development of additional instruments. The results of this longitudinal review can provide future researchers with a broad base of the research that has incorporated Hofstede's work on Uncertainty Avoidance on which to build.

A limitation of our research is that it only considered the articles in the Journal of International Business Studies. However, this limitation also provides the opportunity for future research. In the future, researchers should examine other research-specific journals to ascertain whether the results of this research are supported.

\section{References}

Agarwal, S. (1993). Influence of Formalization on Role Stress, Organizational Commitment, and Work Alienation of Salespersons: A Cross-National Comparative Study, Journal of International Business Studies, 24 (4), 715-739.

$\mathrm{Au}, \mathrm{K}$. Y. (1999). Intra-cultural variation: Evidence and implications for international business, Journal of International Business Studies, 30 (4), 799-812.

Barkema, H. G. \& Vermeulen, F. (1997). What Differences in the Cultural Backgrounds of Partners Are Detrimental for International Joint Ventures? Journal of International Business Studies, 28 (4), 845-864.

Benito, G. R. G. \& Gripsrud, G. (1992). The Expansion of Foreign Direct Investments: Discrete Rational Location Choices or a Cultural Learning Process? Journal of International Business Studies, 23 (3), 461-476.

Bigoness, W. J. \& Blakely, G. L. (1996). A Cross-National Study of Managerial Values, Journal of International Business Studies, 27 (4), 739-752.

Bowen, H. \& De Clercq, D. (2008). Institutional Context and the Allocation of Entrepreneurial Effort, Journal of International Business Studies, 39 (4), 747-768.

Brock, D. M., Shenkar, O., Shoham, A. \& Siscovick, I. C. (2008). National Culture and Expatriate Deployment, Journal of International Business Studies, 39 (8), 1293-1309.

Brouthers, K. D. \& Brouthers, L. E. (2001). Explaining the National Cultural Distance Paradox, Journal of International Business Studies, 32 (1), 177-189.

Buck, T. \& Shahrim, A. (2005). The Translation of Corporate Governance Changes across National Cultures: The Case of Germany, Journal of International Business Studies, 36 (1), 42-61.

Buck, T., Filatotchev, I., Demina, N. \& Wright, M. (2003). Insider Ownership, Human Resource Strategies and Performance in a Transition Economy, Journal of International Business Studies, 34 (6), 530-549.

Celly, K. S., Spekman, R. E. \& Kamauff, J. W. (1999). Technological Uncertainty, Buyer Preferences and Supplier Assurances: An Examination of Pacific Rim Purchasing Arrangements, Journal of International Business Studies, 30 (2), 297-316. 
Chan, C. M. \& Makino, S. (2007). Legitimacy and Multi-Level Institutional Environments: Implications for Foreign Subsidiary Ownership Structure, Journal of International Business Studies, 38 (4), 621-638.

Chui, A. C. W. \& Kwok, C. C. Y. (2008). National Culture and Life Insurance Consumption, Journal of International Business Studies, 39 (1), 88-101.

Chui, A. C. W., Lloyd, A. E. \& Kwok, C. C. Y. (2002). The Determination of Capital Structure: Is National Culture a Missing Piece To The Puzzle? Journal of International Business Studies, 33 (1), 99-127.

Craig, C. S., Douglas, S. P. \& Grein, A. (1992). Patterns of Convergence and Divergence among Industrialized Nations: 1960-1988, Journal of International Business Studies, 23 (4), 773-787.

Dawar, N., Parker, P. M. \& Price, L. J. (1996). A Cross-Cultural Study of Interpersonal Information Exchange, Journal of International Business Studies, 27 (3), 497-516.

DiRienzo, C. E., Das, J., Cort, K. T. \& Burbridge, J. (2007). Corruption and the Role of Information. Journal of International Business Studies, 38 (2), 320-332.

Dow, D. \& Karunaratna, A. (2006). Developing a Multidimensional Instrument to Measure Psychic Distance Stimuli, Journal of International Business Studies, 37 (5), 578-602.

Ellis, P. D. (2008). Does Psychic Distance Moderate the Market Size-Entry Sequence Relationship? Journal of International Business Studies, 39 (3), 351-369.

Erramilli, M. K. (1996). Nationality and Subsidiary Ownership Patterns in Multinational Corporations. Journal of International Business Studies, 27 (2), 225-248.

Evans, J. \& Mavondo, F. T. (2002). Psychic Distance and Organizational Performance: An Empirical Examination of International Retailing Operations, Journal of International Business Studies, 33 (3), 515-532.

Fey, C. F. \& Björkman, I. (2001). The Effect of Human Resource Management Practices on MNC Subsidiary Performance in Russia, Journal of International Business Studies, 32 (1), 59-75.

Frost, T. S. \& Zhou, C. (2005). R\&D Co-Practice and 'Reverse' Knowledge Integration in Multinational Firms, Journal of International Business Studies, 36 (6), 676-687.

Fu, P. P., Kennedy, J., Tata, J., Yukl, G., Bond, M. H., Peng, T-K., Srinivas, E. S., Howell, J. P., Prieto, L., Koopman, P., Boonstra, J. J., Pasa. S., Lacassagne, M-F., Higashide, H. \& Cheosakul, A. (2004). The Impact of Societal Cultural Values and Individual Social Beliefs on the Perceived Effectiveness of Managerial Influence Strategies: A Meso Approach, Journal of International Business Studies, 35 (4), 284-305.

Giacobbe-Miller, J. K., Miller, D. J., Zhang, W. \& Victorov, V. I. (2003). Country and Organizational-Level Adaptation to Foreign Workplace Ideologies: A Comparative Study of Distributive Justice Values in China, Russia and the United States, Journal of International Business Studies, 34 (4), 389-406.

Gibson, C. B. (1995). An Investigation of Gender Differences in Leadership across Four Countries, Journal of International Business Studies, 26 (2), 225-279.

Gomez-Mejia, L. R. \& Palich, L. E. (1997). Cultural Diversity and the Performance of Multinational Firms, Journal of International Business Studies, 28 (2), 309-335.

Griffith, D. A. \& Harvey, M. G. (2001). A Resource Perspective of Global Dynamic Capabilities, Journal of International Business Studies, 32 (3), 597-606.

Griffith, D. A. \& Myers, M. B. (2005). The Performance Implications of Strategic Fit of Relational Norm Governance Strategies in Global Supply Chain Relationships, Journal of International Business Studies, 36 (3), 254-269.

Griffith, D. A., Hu, M. Y. \& Ryans, J. K. (2000). Process Standardization across Intra-and-Inter-Cultural Relationships, Journal of International Business Studies, 31 (2), 303-324.

Hennart, J-F. \& Larimo, J. (1998). The Impact of Culture on the Strategy of Multinational Enterprises: Does National Origin Affect Ownership Decisions? Journal of International Business Studies, 29 (3), 515-538.

Hennart, J-F. \& Zeng, M. (2002). Cross-Cultural Differences and Joint Venture Longevity, Journal of International Business Studies, 33 (4), 699-716.

Heuer, M., Cummings, J. L. \& Hutabarat, W. (1999). Cultural Stability or Change among Managers in Indonesia? Journal of International Business Studies, 30 (3), 599-610. 
Hirst, G., Budhwar, P., Cooper, B. K., West, M., Long, C., Chongyuan, X. \& Shipton, H. (2008). Cross-Cultural Variations in Climate for Autonomy, Stress and Organizational Productivity Relationships: A Comparison of Chinese and UK Manufacturing Organizations, Journal of International Business Studies, 39 (8), 1343-1358.

Hofstede, G. (1983). The Cultural Relativity of Organizational Practices and Theories, Journal of International Business Studies, 14 (2), 75-89.

Hofstede, G. (2006). What did GLOBE really measure? Researchers' Minds versus Respondents' Minds, Journal of International Business Studies, 37 (6), 882-896.

Hofstede, G., Van Deusen, C. A., Mueller, C. B. \& Charles, T. A. (2002). What Goals Do Business Leaders Pursue? A study in fifteen countries, Journal of International Business Studies, 33 (4), 785-803.

Hofstede, G.: (2001). Culture's Consequences, $2^{\text {nd }}$ ed., London: Sage Publications.

Hofstede, G.: (1991). Culture's Consequences, $1^{\text {st }}$ ed., London: Sage Publications.

Huang, X. \& Van de Vliert, E. (2002). Intrinsic Job Rewards at Country-Level and Individual-Level Codetermine Job Satisfaction, Journal of International Business Studies, 33 (2), 385-394.

Husted, B. W. (1999). Wealth, Culture, and Corruption, Journal of International Business Studies, 30 (2), 339-359.

Husted, B. W., Dozier, J. B., McMahon, J. T. \& Kattan, M. W. (1996). The impact of cross-national carriers of business ethics on attitudes about questionable practices and form of moral reasoning, Journal of International Business Studies, 27 (2), 391-411.

Hutzschenreuter, T. \& Voll, J. C. (2008). Performance Effects of "Added Cultural Distance" in the Path of International Expansion: The Case of German Multinational Enterprises, Journal of International Business Studies, 39 (1), 53-70.

Jackson, G. \& Deeg, R. (2008). Comparing Capitalisms: Understanding Institutional Diversity and Its Implications for International Business, Journal of International Business Studies, 39 (4), 540-561.

Javidan, M., House, R. J., Dorfman, P. W., Hanges, P. J. \& de Luque, M. S. (2006). Conceptualizing and Measuring Cultures and their Consequence: A Comparative Review of GLOBE's and Hofstede's Approaches, Journal of International Business Studies, 38 (6), 897-914.

Jensen, R. \& Szulanski, G. (2004). Stickiness and the Adaptation of Organizational Practices in Cross-Border Knowledge Transfers, Journal of International Business Studies, 35 (6), 508-523.

Kale, S. H. \& Barnes, J. W. (1992). Understanding the Domain of Cross-National Buyer-Seller Interactions, Journal of International Business Studies, 23 (1), 101-132.

Kashlak, R. J., Chandran, R. \& Di Benedetto, C. A. (1998). Reciprocity in International Business: A Study of Telecommunications Alliances and Contracts, Journal of International Business Studies, 29 (2), 281-304.

Kirkman, B. L., Lowe, K. B. \& Gibson, C. B. (2006). A quarter Century of “Culture's Consequences: A Review of Empirical Research Incorporating Hofstede's Cultural Values Framework, Journal of International Business Studies, 37 (3), 285-320.

Kogut, B. \& Singh, H. (1988). The Effect of National Culture on the Choice of Entry Mode, Journal of International Business Studies, (19 (3), 411-432.

Kwok, C. C. Y. \& Tadesse, S. (2006a). National Culture and Financial Systems, Journal of International Business Studies, 37 (2), 227-247.

Kwok, C. C. Y. \& Tadesse, S. (2006b). The MNC as an Agent of Change for Host-Country Institutions: FDI and Corruption, Journal of International Business Studies, 37 (6), 767-785.

Lau, C-M. \& Ngo, H-Y. (2001). Organization Development and Firm Performance: A Comparison of Multinational and Local Firms, Journal of International Business Studies, 32 (1), 95-114.

Lenartowicz, T. \& Roth, K. (1999). A Framework for Culture Assessment, Journal of International Business Studies, 30 (4), 781-798.

Leung, K., Bhagat, R. S., Buchan, N. R., Erez, M. \& Gibson, C. B. (2005). Culture and International Business: Recent Advances and Their Implications for Future Research, Journal of International Business Studies, 36 (4), 357-378.

Li, J. \& Guisinger, S. (1992. The Globalization of Service Multinationals in the "Triad" Regions: Japan, Western Europe, and North America, Journal of International Business Studies, 23 (4), 675-696. 
Li, J., Lam, K. \& Qian, G. (2001). Does Culture Affect Behavior and Performance of Firms? The case of joint ventures in China, Journal of International Business Studies, 32 (1), 115-131.

Lim, K. H., Leung, K., Sia, C. L. \& Lee, M. K. D. (2004). Is eCommerce Boundary-Less? Effects of individualism-collectivism and uncertainty avoidance on internet shopping, Journal of International Business Studies, 35 (6), 545-559.

Ling, Y., Floyd, S. W. \& Baldridge, D. C. (2005). Toward a Model of Issue-Selling by Subsidiary Managers in Multinational Organizations, Journal of International Business Studies, 36 (6), 637-654.

Loree, D. W. \& Guisinger, S. E. (1995). Policy and Non-Policy Determinants of U.S. Equity Foreign Direct Investment, Journal of International Business Studies, 26 (2), 281-299.

Luo, Y. (2003). Market-Seeking MNEs in an Emerging Market: How Parent-Subsidiary Links Shape Overseas Success, Journal of International Business Studies, 34 (3), 290-309.

Luo, Y. (2006). Political Behavior, Social Responsibility, and Perceived Corruption: A Structuration Perspective, Journal of International Business Studies, 37 (6), 747-766.

Luo, Y. (2007). An Integrated Anti-Opportunism System in International Exchange, Journal of International Business Studies, 38 (6), 855-877.

Luo, Y. \& Park, S. H. (2004). Multiparty Cooperation and Performance in International Equity Joint Ventures, Journal of International Business Studies, 35 (2), 142-160.

Luo, Y. \& Peng, M. W. (1999). Learning to Compete in a Transition Economy: Experience, Environment, and Performance, Journal of International Business Studies, 30 (2), 269-295.

Lynch, P. D. \& Beck, J. C. (2001). Profiles of Internet Buyers in 20 Countries: Evidence for Region-Specific Strategies, Journal of International Business Studies, 32 (4), 725-748.

Makhija, M. V. \& Stewart, A. C. (2002). The Effect of National Context on Perceptions of Risk: A Comparison of Planned versus Free-Market Managers, Journal of International Business Studies, 33 (4), 737-756.

Manev, I. M. \& Stevenson, W. B. (2001). Nationality, Cultural Distance, and Expatriate Status: Effects on the Managerial Network in a Multinational Enterprise, Journal of International Business Studies, 32 (2), 285-303.

Markides, C. C. \& Ittner, C. D. (1994). Shareholder Benefits from Corporate International Diversification: Evidence from U.S. International Acquisitions, Journal of International Business Studies, 25 (2), 343-366.

Maznevski, M. L. (1994). Understanding Global Cultures: Metaphorical Journeys through 17 Countries, Journal of International Business Studies, 25 (3), 662-666.

McNamara, G. \& Vaaler, P. M. (2000). The Influence of Competitive Positioning and Rivalry on Emerging Market Risk Assessment, Journal of International Business Studies, 31 (2), 337-347.

Mezias, J. M. \& Scandura, T. A. (2005). A Needs-Driven Approach to Expatriate Adjustment and Career Development: A Multiple Mentoring Perspective, Journal of International Business Studies, 36 (5), 5(19-538.

Miller, J. S., Hom, P. W. \& Gomez-Mejia, L. R. (2001). The High Cost of Low Wages: Does Maquiladora Compensation Reduce Turnover? Journal of International Business Studies, 32 (3), 585-595.

Miller, K. D. (1992). A Framework for Integrated Risk Management in International Business, Journal of International Business Studies, 23 (2), 311-331.

Money, R. B. (1998). International Multilateral Negotiations and Social Networks, Journal of International Business Studies, 29 (4), 695-710.

Morosini, P., Shane, S. \& Singh, H. (1998). National Cultural Distance and Cross-Border Acquisition Performance, Journal of International Business Studies, 29 (1), 137-158.

Nadolska, A. \& Barkema, H. G. (2007). Learning to Internationalise: The Pace and Success of Foreign Acquisitions, Journal of International Business Studies, 38 (7), 1170-1186.

Neelankavil, J. P., Mathur, A. \& Zhang, Y. (2000). Determinants of Managerial Performance: A Cross-Cultural Comparison of the Perceptions of Middle-Level Managers in Four Countries, Journal of International Business Studies, 31 (1), 121-140.

Newburry, W. \& Yakova, N. (2006). Standardization Preferences: A Function of National Culture, Work Interdependence and Local Embeddedness, Journal of International Business Studies, 37 (1), 44-60. 
Newman, K. L. \& Nollen, S. D. (1996). Culture and Congruence: The Fit between Management Practices and National Culture, Journal of International Business Studies, 27 (4), 753-779.

Nye, C. W., Roth, M. S. \& Shimp, T. A. (2008). Comparative Advertising in Markets where Brands and Comparative Advertising Are Novel, Journal of International Business Studies, 39 (5), 851-863.

O’Grady, S. \& Lane, H. W. (1996). The Psychic Distance Paradox, Journal of International Business Studies, 27 (2), 309-333.

Pan, Y. (1996). Influences on Foreign Equity Ownership Level in Joint Ventures in China, Journal of International Business Studies, 27 (1), 1-26.

Pan, Y. (2002). Equity Ownership in International Joint Ventures: The Impact of Source Country Factors, Journal of International Business Studies, 33 (2), 375-384.

Pan, Y. \& Tse, D. K. (1996). Cooperative Strategies between Foreign Firms in an Overseas Country, Journal of International Business Studies, 27 (5), 929-946.

Parboteeah, K. P., Hoegl, M. \& Cullen, J. B. (2008). Managers' Gender Role Attitudes: A Country Institutional Profile Approach, Journal of International Business Studies, 39 (5), 795-813.

Pellegrini, E. K. \& Scandura, T. A. (2006). Leader-Member Exchange (LMX), Paternalism, and Delegation in the Turkish Business Culture: An Empirical Investigation, Journal of International Business Studies, 37 (2), 264-279.

Pothukuchi, V., Damanpour. F., Choi, J. Chen, C. C. \& Park, S. H. (2002). National and Organizational Culture Differences and International Joint Venture Performance, Journal of International Business Studies, 33 (2), 243-265.

Ralston, D. A., Gustafson, D. J., Cheung, F. M. \& Terpstra, R. H. (1993). Differences in Managerial Values: A Study of U.S., Hong Kong and PRC managers, Journal of International Business Studies, 24 (2), 249-275.

Ralston, D. A., Holt, D. H., Terpstra, R. H. \& Kai-Cheng, Y. (1997). The Impact of National Culture and Economic Ideology and Managerial Work Values: A Study of the United States, Russia, Japan, and China, Journal of International Business Studies, 28 (1), 177-207.

Rao, A. \& Hashimoto, K. (1996). Intercultural Influence: A Study of Japanese Expatriate Managers in Canada, Journal of International Business Studies, 27 (3), 443-466.

Reuer, J. J., Shenkar, O. \& Ragozzino R. (2004). Mitigating Risk in International Mergers and Acquisitions: The role of contingent payouts, Journal of International Business Studies, 35 (1), (19-32.

Salter, S. B. \& Niswander, F. (1995). Cultural Influence on the Development Of Accounting Systems Internationally: A Test of Gray's [1988] Theory, Journal of International Business Studies, 26 (2), 379-397.

Schuler, R. S. \& Rogovsky, N. (1998). Understanding Compensation Practice Variations across Firms: The Impact of National Culture, Journal of International Business Studies, 29 (1), 159-177.

Shane, S. (1995). Uncertainty Avoidance and the Preference for Innovation Championing Roles, Journal of International Business Studies, 26 (1), 47-68.

Shenkar, O. (2001). Cultural Distance Revisited: Towards A More Rigorous Conceptualization and Measurement of Cultural Differences, Journal of International Business Studies, 32 (3), 5(19-535.

Shenkar, O. \& Zeira, Y. (1992). Role Conflict and Role Ambiguity of Chief Executive Officers in International Joint Ventures, Journal of International Business Studies, 23 (1), 55-75.

Sirmon, D. G. \& Lane, P. J. (2004). A Model of Cultural Differences and International Alliance Performance, Journal of International Business Studies, 35 (4), 306-3(19.

Sivakumar, K. \& Nakata, C. (2001). The Stampede toward Hofstede's Framework: Avoiding the Sample Design Pit in Cross-Cultural Research, Journal of International Business Studies, 32 (3), 555-574.

Slangden, A. H. L. \& Hennart, J-F. (2008). Do Multinationals Really Prefer to Enter Culturally Distant Countries through Greenfields Rather than through Acquisitions? The Role of Parent Experience and Subsidiary Autonomy, Journal of International Business Studies, 39 (3), 472-490.

Smith, P. B. (2006). When Elephants Fight, the Grass Gets Trampled: The GLOBE and Hofstede Projects, Journal of International Business Studies, 37 (6), 915-921.

Smith, P. B., Peterson, M. F. \& Wang, Z. M. (1996). The Manager as Mediator of Alternative Meanings: A Pilot Study from China, the USA and U.K., Journal of International Business Studies, 27 (1), 115-137. 
Soutar, G. N., Grainger, R. \& Hedges, P. (1999). Australian and Japanese Value Stereotypes: A Two-Country Study, Journal of International Business Studies, 30 (1), 203-216.

Speck, S. K. S. \& Roy, A. (2008). The Interrelationships between Television Viewing, Values and Perceived Well-Being: A Global Perspective, Journal of International Business Studies, 39 (7), 1(197-12(19.

Steenkamp, J-B. E. M., Batra, R. \& Alden, D. L. (2003). How Perceived Brand Globalness Creates Brand Value, Journal of International Business Studies, 34 (1), 53-65.

Tallman, S. B. \& Shenkar, O. (1994). A Managerial Decision Model of International Cooperative Venture Formation, Journal of International Business Studies, 25 (1), 91-113.

Tang, L. \& Koveos, P. E. (2008). A Framework to Update Hofstede's Cultural Value Indices: Economic Dynamics and Institutional Stability, Journal of International Business Studies, 39 (6), 1045-1063.

Thomas, A. S. \& Mueller, S. L. (2000). A Case for Comparative Entrepreneurship: Assessing the Relevance of Culture, Journal of International Business Studies, 31 (2), 287-301.

Thomas, A. S., Shenkar, O. \& Clarke, L. (1994). The Globalization of our Mental Maps: Evaluating the Geographic Scope of JIBS Coverage, Journal of International Business Studies, 25 (4), 675-686.

Tihanyi, L., Griffith, D. A. \& Russell, C. J. (2005). The Effect of Cultural Distance on Entry Mode Choice, International Diversification, and MNE Performance: A Meta-Analysis, Journal of International Business Studies, 36 (3), 270-283.

Trompenaars, F. \& Hampden-Turner, C. (1998). Riding the waves of culture, $2^{\text {nd }}$ ed. McGraw-Hill: New York.

Tse, D. K., Pan, Y. \& Au, K. Y. (1997). How MNCs Choose Entry Modes and Form Alliances: The China Experience, Journal of International Business Studies, 28 (4), 779-805.

Ueno, S. \& Sekaran, U. (1992). The Influence of Culture on Budget Control Practices in the USA and Japan: An Empirical Study. Journal of International Business Studies, 23 (4), 659-674.

Uhlenbruck, K. (2004). Developing Acquired Foreign Subsidiaries: The Experience of MNES in Transition Economies, Journal of International Business Studies, 35 (2), 109-123.

Van de Vliert, E. (2003). Thermoclimate, Culture, and Poverty as Country-Level Roots of Workers' Wages, Journal of International Business Studies, 34 (1), 40-52.

Wu, C., Lawler, J. J. \& Yi, X. (2008). Overt Employment Discrimination in MNC Affiliates: Home-Country Cultural and Institutional Effects, Journal of International Business Studies, 39 (5), 772-794.

Yan, A. \& Zeng, M. (1999). International Joint Venture Instability: A Critique of Previous Research, a Reconceptualization, and Directions for Future Research, Journal of International Business Studies, 30 (2), 397-414.

Yeh, R-S. \& Lawrence, J. J. (1995). Individualism and Confucian Dynamism: A Note on Hofstede's Cultural Root to Economic Growth, Journal of International Business Studies, 26 (3), 655-669.

Zaheer, S. (1995). Circadian Rhythms: The Effects of Global Market Integration in the Currency Trading Industry, Journal of International Business Studies, 26 (4), 699-728.

Zaheer, S. \& Zaheer, A. (1997). Country Effects on Information Seeking in Global Electronic Networks, Journal of International Business Studies, 28 (1), 77-100.

Zhang, C. Cavusgil, S. T., \& Roath, A. S. (2003). Manufacturer Governance of Foreign Distributor Relationships: Do Relational Norms Enhance Competitiveness in the Export Market? Journal of International Business Studies, 34 (6), 550-566.

\section{Notes}

Note 1. In 1980s there was no online database for journals. The second author recalls developing the literature review for his dissertation in 1989 and 1990. He spent most of his free time searching through hard copies of journals for relevant articles. Consequently, a five-year lag between the publication of an article such as Hofstede's in 1983 and the first use of his research in subsequent research in 1988 was not unusual especially if one considers the submission, review and publication processes. 
Table 1. Notes section and definition articles

\begin{tabular}{|c|c|c|c|}
\hline Author(s) & Year & Sample & Major Finding(s) \\
\hline \multicolumn{4}{|c|}{ Panel A: Notes Section Articles } \\
\hline Jackson \& Deeg & 2008 & Theory development & Used Hofstede in literature review. \\
\hline Speck \& Roy & 2008 & $\begin{array}{l}\text { Argentina, Chile, China, Croatia, India, Lebanon, } \\
\text { Mexico, New Zealand, Poland, Slovenia, Turkey, } \\
\text { U.A.E., U.S. }\end{array}$ & Effects of materialism and television viewing on perception of well-being \\
\hline Tihanyi et al. & 2005 & U.S.-based Multi-National Corporation & $\begin{array}{l}\text { Used Hofstede to code Multi-National Enterprises. Found strong negative } \\
\text { association between cultural distance and entry mode choice for US-based } \\
\text { Multi-National Enterprise }\end{array}$ \\
\hline \multicolumn{4}{|c|}{ Panel B: Definition Articles } \\
\hline Bigoness \& Blakely & 1996 & $\begin{array}{l}\text { Australia, Brazil, Denmark, France, Germany, } \\
\text { Italy, Japan, Netherlands, Norway, Sweden, U.K., } \\
\text { U.S. }\end{array}$ & $\begin{array}{l}\text { Used Hofstede in literature review. Found } 4 \text { managerial values that differentiated } \\
\text { among cultures }\end{array}$ \\
\hline Giacobbe-Miller et al. & 2003 & China, Russia, U.S. & Effects of culture on distributive justice values \\
\hline Gibson & 1995 & Australia, Norway, Sweden, U.S. & Country differences in leadership styles were found \\
\hline Lenartowicz \& Roth & 1999 & Theory development & Suggest another framework for culture assessment \\
\hline Ling et al. & 2005 & Theory development & $\begin{array}{l}\text { Influence of culture on "issue selling" approaches by subsidiary managers in } \\
\text { Multi-National Corporations }\end{array}$ \\
\hline Lynch \& Beck & 2001 & 20 country sample & Impact of culture on internet-buying behaviors \\
\hline Neelankavil et al. & 2000 & China, India, Philippines, U.S. & $\begin{array}{l}\text { Impact of culture on senior manager's perception of middle manager } \\
\text { performance }\end{array}$ \\
\hline Newman \& Nollen & 1996 & US with 18 non-US subsidiaries & $\begin{array}{l}\text { Effect of congruence of management practices and culture on Multi-National } \\
\text { Enterprise performance }\end{array}$ \\
\hline Ralston et al. & 1997 & China, Japan, Russia, U.S. & $\begin{array}{l}\text { Used Hofstede as a literature review item. Used Schwartz instrument for } \\
\text { divergence or convergence of manager's work values. }\end{array}$ \\
\hline Yeh \& Lawrence & 1995 & Literature review & Critique of Hofstede's link between culture and economic growth \\
\hline
\end{tabular}

Table 2a. Research hypotheses articles - No Sample

\begin{tabular}{|l|l|l|l|}
\hline Author(s) & Year & Use of Uncertainty Avoidance & \multicolumn{2}{l|}{ Major Finding(s) } \\
\hline Leung et al. & 2005 & Review of cultural research & Need for a more complex methodology in examining the effects of culture \\
\hline Maznevski & 1994 & Book review & Use of metaphors to understand 17 countries \\
\hline Mezias \& Scandura & 2005 & Theory development & Effect of mentoring on expatriate adjustment and career development \\
\hline Miller & 1992 & Theory development & $\begin{array}{l}\text { Framework for integrated risk management at the strategic level in international } \\
\text { business }\end{array}$ \\
\hline Money & 1998 & Theory development & Impact of culture on international multilateral negotiations \\
\hline Shenkar & 2001 & Theory development & Need for better measure of cultural distance \\
\hline Sirmon \& Lane & 2004 & Theory development & Impact of cultural differences on international firm alliances \\
\hline Smith & 2006 & Discussion & Analysis of debate between GLOBE and Hofstede \\
\hline Tallman \& Shenkar & 1994 & Theory development & $\begin{array}{l}\text { Effect of culture on decision-making model of Multi-National Enterprise executives } \\
\text { regarding international cooperative ventures }\end{array}$ \\
\hline Thomas et al. & 1994 & Discussion & Patterns of country coverage in the Journal of International Business Studies \\
\hline Yan \& Zeng & 1999 & Discussion & Review of literature on international joint venture instability \\
\hline
\end{tabular}


Table $2 b$. Research hypotheses articles - Samples of one-or-two countries

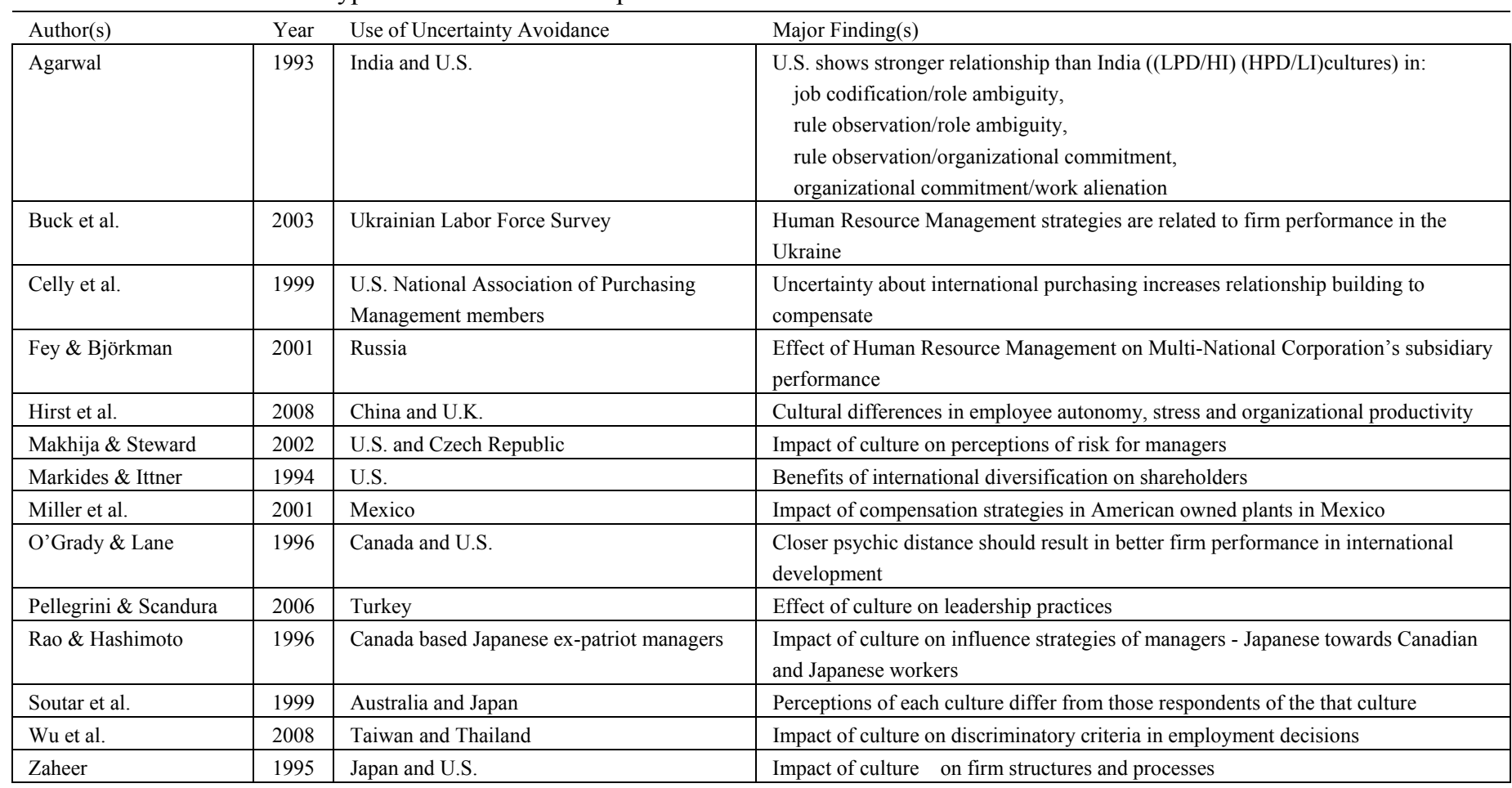

HI High Individualism

HPD High Power Distance

LI Low Individualism

LPD Low Power Distance

Table 2c. Research hypotheses articles - Samples of three-or-more countries

\begin{tabular}{|c|c|c|c|}
\hline Author(s) & Year & Sample & Major Finding(s) \\
\hline Chui et al. & 2002 & Worldscope data base & National culture affects corporate capital structures \\
\hline DiRienzo et al. & 2007 & 85 countries & $\begin{array}{l}\text { Impact of economic, cultural, information and communication } \\
\text { technology on corruption }\end{array}$ \\
\hline Griffith et al. & 2000 & Canada, Chile, Mexico, U.S. & Effect of culture on relationship development strategies \\
\hline Hofstede et al. & 2002 & 21 country sample & Goals of business leaders \\
\hline Huang \& Van de Vliert & 2002 & International Society Survey Program - 19 country sample & Determinants of job satisfaction \\
\hline Husted et al. & 1996 & Mexico, Spain, U.S. & Cultural differences in moral reasoning \\
\hline Javidan et al. & 2006 & GLOBE and Hofstede's data & Refutation of Hofstede's critique of GLOBE \\
\hline Kashlak et al. & 1998 & US and 109 countries & $\begin{array}{l}\text { Effects of culture, economics, and governance mechanism on } \\
\text { reciprocity in business alliances }\end{array}$ \\
\hline Kwok \& Tadesse & $\begin{array}{c}2006 \\
b\end{array}$ & Data set of 140 countries & Effect of presence of Multi-National Enterprises on corruption \\
\hline Lau \& Ngo & 2001 & Europe, Hong Kong, Japan, U.S. & $\begin{array}{l}\text { Effect of OD interventions on multinational firms and employee } \\
\text { performance }\end{array}$ \\
\hline Li et al. & 2001 & $\begin{array}{l}\text { China's Third Industry Census - Australia, Canada, China, } \\
\text { France, Germany, Great Britain, Japan, Macao, North Korea, } \\
\text { Singapore, South Korea, Taiwan, U.S. }\end{array}$ & $\begin{array}{l}\text { Effect of culture on behavior and performance of firms - joint } \\
\text { ventures }\end{array}$ \\
\hline Manev \& Stevenson & 2001 & U.K. Multi-National Enterprises and subsidiaries in 36 countries & Culture on manager's network ties in a Multi-National Enterprise \\
\hline McNamera \& Vaaler & 2000 & $\begin{array}{l}\text { Ratings from the Nationally Recognized Statistical Rating } \\
\text { Organization agencies - six agencies }\end{array}$ & Credit rating risk assessments of emerging market borrowers \\
\hline Ralston et al. & 1993 & China, Hong Kong, U.S. & Effect of culture on differences in managerial values \\
\hline Sivakumar \& Nakata & 2001 & $\begin{array}{l}\text { Arab Countries, Argentina, Australia, Austria, Brazil, Canada, } \\
\text { Denmark, East Africa, El Salvador, Finland, France, Germany, } \\
\text { Greece, Guatemala, Hong Kong, Ireland, Israel, Jamaica, Japan, } \\
\text { Malaysia, Netherlands, Norway, Panama, Peru, Portugal, } \\
\text { Singapore, South Korea, Spain, Sweden, Switzerland, Turkey, } \\
\text { U.K., U.S., Venezuela, West Africa }\end{array}$ & $\begin{array}{l}\text { Methodology to perform better multi-country analyses using } \\
\text { Hofstede's cultural constructs. }\end{array}$ \\
\hline Smith et al. & 1996 & Hong Kong, Japan, U.K., U.S. & Impact of culture on manager's handling of work events \\
\hline
\end{tabular}


Table 3a. Cultural Distance Index Articles - Used Kogut \& Singh's Index

\begin{tabular}{|c|c|c|c|}
\hline Author(s) & Year & Sample & Major Finding(s) \\
\hline Barkema \& Vermeulen & 1997 & 25 firms & KSI to compute cultural distance \\
\hline Benito \& Gripsrud & 1992 & 201 cases & $\begin{array}{l}\text { KSI as measure of cultural distance between Norway and Foreign Direct } \\
\text { Investment countries }\end{array}$ \\
\hline Dow \& Karunaratna & 2006 & 38 countries & Talk about what many researchers do \\
\hline Ellis & 2008 & 924 market entries & UA defining factor for firm internationalization \\
\hline Frost \& Zhou & 2005 & 104 multinational & KSI to calculate cultural distance as sum of standard differences \\
\hline Gomez-Megia \& Palich & 1997 & 100 firms & KSI to calculate a composite cultural distance index for each firm \\
\hline Hennart \& Larimo & 1998 & 38 ventures & KSI to measure cultural distance between Japan \& US; Finland \& US. \\
\hline Hennart \& Zeng & 2002 & 97 joint ventures & KSI as a proxy for unexpected changes in the external economic environ. \\
\hline Hutzschenreuter \& Voll & 2008 & 135 companies & Cultural distance measured in accordance with KSI \\
\hline Jensen \& Szulanski & 2004 & 271 questionnaires & KSI to measure distance between source and receiver countries \\
\hline Kogut \& Singh & 1988 & 228 entries & Built the KSI using Hofstede's indices - based on four cultural dimensions \\
\hline Li \& Guisinger & 1992 & 9 service industries & KSI to measure cultural distance between home and host countries \\
\hline Loree \& Guisinger & 1995 & Benchmark studies & KSI to measure deviation for each host country \\
\hline Luo & 2006 & 126 questionnaires & KSI to measure cultural distance \\
\hline Luo & 2007 & 192 International Joint Ventures & Obtained five Cultural Distances - controlled variables for tests \\
\hline Luo & 2003 & 196 Multi-National Enterprise & KSI to measure cultural distance \\
\hline Luo \& Park & 2004 & Multiple samples & Measured cultural distance using KSI \\
\hline Luo \& Peng & 1999 & 108 questionnaires & Computed cultural distance using KSI \\
\hline Morosini et al. & 1998 & 52 companies & UA can influenced post-acquisition performance and controlled for KSI \\
\hline Nadolska \& Barkema & 2007 & 265 companies & Cultural differences between host and home country using KSI \\
\hline Pan & 1996 & 4,223 International Joint Ventures & KSI to measure uncertainty avoidance \\
\hline Pan \& Tse & 1996 & 4,223 International Joint Ventures & KSI for all of Hofstede's cultural dimensions \\
\hline Slangden \& Hennart & 2008 & 36 countries & Cultural Distance between the Netherlands and 35 host countries through KSI \\
\hline Thomas \& Mueller & 2000 & 1,800 responses & $\begin{array}{l}\text { Cultural Distance used to determine systematic variation across cultures using } \\
\text { KSI }\end{array}$ \\
\hline
\end{tabular}

Table 3b. Cultural Distance Index Articles - Used index similar to KSI

\begin{tabular}{|l|l|l|l|}
\hline \multicolumn{1}{l}{ Author(s) } & Year & \multicolumn{1}{l}{ Sample } & \multicolumn{2}{l}{ Major Finding(s) } \\
\hline Chan \& Makino & 2007 & 4,451 subsidiaries & Built on Kogut and Singh's formula to measure national cultural distance \\
\hline Evans \& Mavondo & 2002 & 102 senior executives & Composite index based on KSI used as basis for psychological. distance \\
\hline Griffith \& Harvey & 2001 & 4 distributors & Used approach similar to the KSI over each dimension's variance \\
\hline Pothukuchi et al. & 2002 & 127 joint ventures & Applied aggregate index similar to KSI to measure cultural distance. \\
\hline Uhlenbruck & 2004 & 170 acquisitions & Modified KSI for Trompenaars \& Hampden-Turner's data \\
\hline
\end{tabular}

KSI Kogut \& Singh's Index 
Table 4a. Research using uncertainty avoidance as an independent or control variable - Firm/data base samples

\begin{tabular}{|c|c|c|c|}
\hline Author(s) & Year & Sample & Major Finding(s) \\
\hline $\mathrm{Au}$ & 1999 & 42 cultures & Intra-cultural Variation is smaller (larger) in high (low) UA cultures \\
\hline Brouthers \& Brouthers & 2001 & 4 home \& 5 target & Construct is absolute difference between home and target country \\
\hline Chui \& Kwok & 2008 & 41 countries & Life insurance consumption and UA association not significant \\
\hline Craig et al. & 1992 & U.N. Statistical data & Comparison 10-time blocks from (1950 to 1988). \\
\hline Erramilli & 1996 & 337 subsidiaries & Values representing UA tendency of Multinational Corporation's home countries \\
\hline Husted & 1999 & Published sources & Hofstede's four cultural constructs as independent variables \\
\hline Kirkman et al. & 2006 & 180 studies & Counterintuitive findings \\
\hline Kwok \& Tadesse & $2006 \mathrm{a}$ & Global data & Countries of higher UA are more likely to have a bank-based system \\
\hline Lim et al. & 2004 & 33 countries & Internet shopping rate negatively related to UA \\
\hline Pan & 2002 & $\begin{array}{l}\text { 8,078 International Joint } \\
\text { Ventures - China }\end{array}$ & High UA countries have higher equity ownership in International Joint Ventures in China \\
\hline Shenkar \& Zeira & 1992 & 44 International Joint Ventures & UA negatively correlated with role ambiguity \\
\hline Steenkamp et al. & 2003 & Korea \& U.S. & Korea belongs to top half of countries surveyed on UA \\
\hline Tang \& Koveos & 2008 & GDP analysis & Gross Domestic Product log graphs and cultural constructs \\
\hline Tse et al. & 1997 & $\begin{array}{l}\text { 2,998 Foreign Business } \\
\text { Activities }\end{array}$ & UA did not register any significant influence in any equations \\
\hline Ueno \& Sekaran & 1992 & 2 countries & UA might exert an equal \& opposite effect on budget structuring \\
\hline Van de Vliert & 2003 & 58 countries & UA not significant in over/under payment \\
\hline Zaheer \& Zaheer & 1997 & 25 countries & Classified countries as either high or low on UA \\
\hline
\end{tabular}

UA Uncertainty Avoidance construct

Table 4b. Research using uncertainty avoidance as an independent or control variable - Human samples

\begin{tabular}{|c|c|c|c|}
\hline Author(s) & Year & Sample & Major Finding(s) \\
\hline Brock et al. & 2008 & 298 general managers & Difference between Headquarters and host country UA \\
\hline Dawar et al. & 1996 & 619 MBA students & UA was correlated with country-level index of opinion seeking \\
\hline Heuer et al. & 1999 & $\begin{array}{l}46 \text { MBAs \& } 22 \text { middle managers from Indonesia } \\
\text { and } 104 \text { MBAs students from the U.S. }\end{array}$ & UA between US and Indonesia \\
\hline Newburry \& Yakova & 2006 & 398 employees & Higher country UA positively related with employee preferences \\
\hline Nye et al. & 2008 & 705 college students & Students (from three countries) exhibited greater cross-national homogeneity \\
\hline
\end{tabular}

UA Uncertainty Avoidance construct

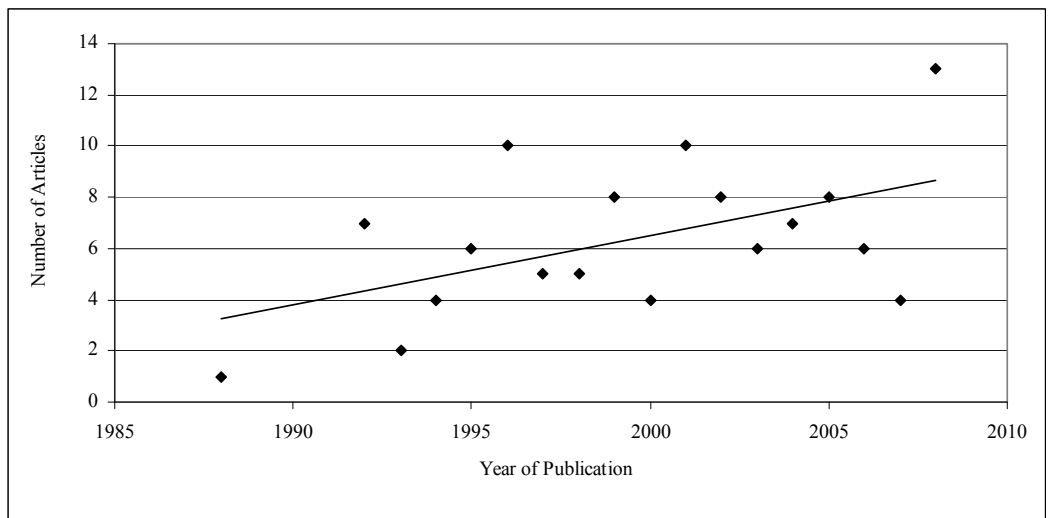

Figure 1. Number of articles using Hofstede's uncertainty avoidance in the Journal of International Business Studies by year 